\title{
PERANCANGAN APLIKASI SISTEM PENGGAJIAN KARYAWAN MENGGUNAKAN VB.NET DI PPILN WIL. JAWA BARAT
}

\author{
Mindit Eriyadi, S.Pd., M.T, \\ Dosen Program Studi Manajemen Informatika \\ Politeknik LP3I Bandung \\ e-mail : mindit.e.plb@yahoo.com
}

\begin{abstract}
Abstrak : Komputer adalah serangkaian atau pun sekelompok mesin elektronik yang terdiri dari ribuan bahkan jutaan komponen yang dapat saling bekerjasama, serta membentuk sebuah sistem yang rapi dan teliti. Sistem ini kemudian dapat digunakan untuk melaksanakan serangkaian pekerjaan secara otomatis, berdasarkan urutan program yang di berikan kepadanya.

PPILN (Perkumpulan Perlindungan Instalasi Listrik Nasional) adalah suatu lembaga inspeksi teknik yang melaksanakan pemeriksaan, penguji dan menerbitkan Sertifikat Laik Operasi (SLO) instalasi pemanfaatan tenaga listrik tegangan rendah bagi instalasi listrik yang sudah memenuhi standar, yang telah ditetapkan oleh kementrian Energi dan Sumber Daya Mineral (ESDM).
\end{abstract}

Kata Kunci : Tata Kelola TI, Sistem Penggajian, Sistem Penggajian Karyawan, Sistem Informasi

\section{Pendahuluan}

Gaji adalah suatu bentuk balas jasa atau pun penghargaan yang diberikan secara teratur kepada seorang pegawai atas jasa dan hasil kerjanya. Gaji sering juga disebut sebagai upah, dimana keduanya merupakan suatu bentuk kompensasi, yakni imbalan jasa yang diberikan secara teratur atas prestasi kerja yang diberikan kepada seorang pegawai. Perbedaan gaji upah hanya terletak pada kuatnya ikatan kerja dan jangka waktu penerimaannya. Seseorang menerima gaji apabila ikatan kerjanya kuat, sedangkan seseorang menerima upah apabila ikatan kerjanya kurang kuat.

Dilihat dari jangka waktu penerimaannya, gaji pada umumnya diberikan pada setiap akhir bulan, sedangkan upah diberikan pada setiap hari atau pun setiap minggu. Dalam hal ini, pengertian gaji untuk seterusnya disebut sebagai gaji pokok. Besarnya gaji pokok yang diberikan kepada seorang karyawan, biasanya sangat tergantung dengan latar belakang pendidikan yang dimiliki, kemampuan maupun pengalaman kerjanya.

Gaji karyawan perusahaan PPILN (Perkumpulan Perlindungan Instalasi Listrik Nasional), pada umumnya akan dibagikan pada setiap akhir bulan. Dengan demikian kesibukan atau pun kegiatan yang dilakukan oleh bagian keuangan pada saat itu adalah mengumpulkan formulir lembur dan hutang, menghitung rupiah lembur masing - masing karyawan, menghitung hutang piutang karyawan, membuat rekapitulasi gaji, membuat slip gaji untuk masing - masing karyawan, mengambil uang dari bank, dan membagi uang kepada setiap karyawan.

Sistem administrasi penggajian yang diterapkan seperti halnya yang ada diatas, sebenarnya sudah baik dan sudah memenuhi beberapa persyaratan prosedur akuntansi. Dikarenakan sistem tersebut masih diterapkan dengan cara manual, maka berbagai persoalan pada akhirnya muncul, seperti misalnya : 
a. Waktu yang diperlukan untuk pembuatan berbagai macam laporan yang berhubungan dengan sistem penggajian karyawan menjadi lama.

b. Informasi data yang disajikan menjadi kurang teliti, misalnya: banyak dijumpai data ganda atau pun data yang kurang lengkap.

c. Proses auditing sewaktu - waktu sulit dilaksanakan.

d. Sering terjadi masalah karena salah perhitungan dan pembayaran gaji yang kurang sesuai dengan yang dikerjakan.

Dikarenakan hal tersebut diatas, kemudian disusun sebuah program komputer mengenai penggajian. Dimana sistem ini diharapkan mampu memberikan solusi terbaik dari berbagai masalah yang ada di PPILN (Perkumpulan Perlindungan Instalasi Listrik Nasional) tersebut.

Peranan komputerisasi dalam mengelola data menjadi suatu informasi yang berguna untuk kemajuan PPILN (Perkumpulan Perlindungan Instalasi Listrik Nasional) sangatlah dibutuhkan karena berfungsi sebagai sarana penunjang lancarnya suatu pekerjaan, khususnya dalam penanganan data penggajian karyawan. Program komputer yang ada disini tidak akan mengubah struktur organisasi yang ada didalam perusahaan, arus dokumen atau pun prosedur - prosedur lainnya. Walaupun demikian, beberapa formulir yang akan digunakan sebagai input data dalam proses komputer, akan mengalami sedikit penyesuaian, demikian pula bentuk format dari laporan - laporan yang akan disajikan melalui komputer.

\section{Sistem Yang Berjalan}

Untuk saat ini di PPILN (Perkumpulan Perlindungan Instalasi Listrik Nasional) dalam hal penggajian belum terdapat sebuah prosedur yang terkomputerisasi, semua proses pencatatan data penggajian dilakukan secara manual. Berikut sedikit gambaran mengenai proses penggajian yang saat ini berjalan di PPILN (Perkumpulan Perlindungan Instalasi Listrik Nasional).

\section{Kebutuhan Pengguna}

Berdasarkan hasil wawancara yang dilakukan dengan salah seorang karyawan PPILN (Perkumpulan Perlindungan Instalasi Listrik Nasional)? pada dasarnya menginginkan sebuah aplikasi yang sederhana serta mudah digunakan namun tetap mampu memberikan kemudahan proses penggajian di PPILN (Perkumpulan Perlindungan Instalasi Listrik Nasional). Ada beberapa hal mereka inginkan dalam pembuatan aplikasi penggajian karyawan ini :

Aplikasi yang dibuat haruslah sederhana dan mudah digunakan.

1. Output / laporan yang dihasilkan harus jelas dan sesuai serta mampu dipertanggung jawabkan.

2. Memiliki tampilan yang sederhana namun tetap dinamis. 


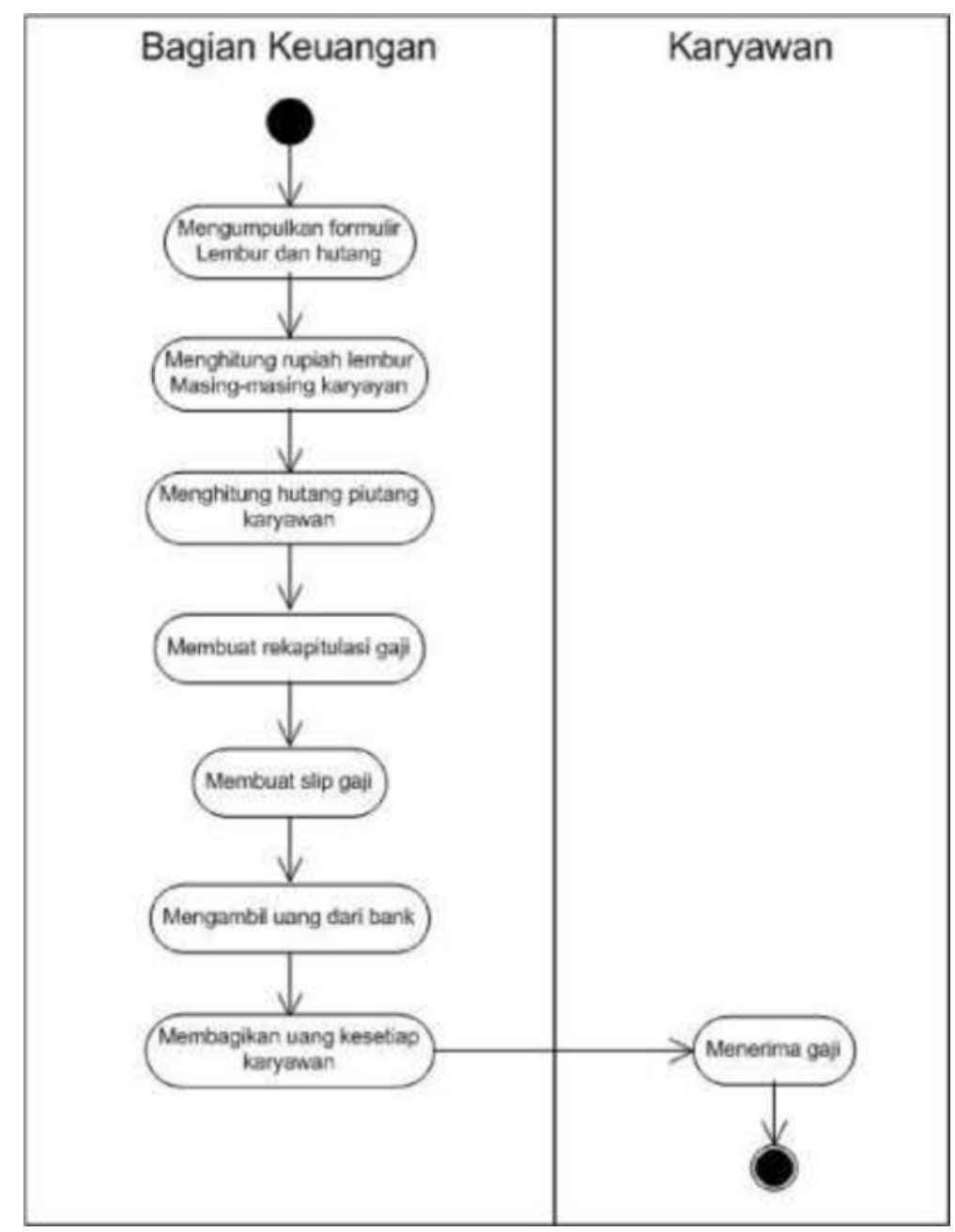

Activity Diagram Sistem Penggajian Secara Manual

\section{Ruang Lingkup}

Permasalahan di PPILN (Perkumpulan Perlindungan Instalasi Listrik Nasional) ini cukup luas, untuk itu perlu adanya pembatasan masalah agar dalam proses pelaksanaan penelitiannya tidak menyimpang dan tetap dalam pokok pembahasannya. Berdasarkan rumusan masalah tersebut, maka penulis akan membatasi proses penelitiannya dengan hanya terfokus terhadap pencatatan penggajian karyawan :

a. Pembahasan dan analisis data hanya meliputi proses pancatatan sistem penggajian karyawan.

b. Aplikasi ini hanya bisa digunakan oleh pengguna atau user yang memiliki hak akses. Sistem informasi yang penulis buat ini adalah aplikasi dalam bentuk aplikasi desktop menggunakan bahasa pemograman Visual Basic 2010 dan dengan database MySQL. 


\section{Pembahasan}

5.1 Kebutuhan Hardware

Adapun Hardware yang dibutuhkan untuk mengimplementasi program aplikasi pencatatan tok ini antara lain :

a. Komputer dengan Spesifikasi minimal

1) Processor Intel Celeron, Pentium IV atau lebih.

2) Memory $4.00 \mathrm{~GB}$ atau lebih.

3) Harddisk $40 \mathrm{~Gb}$ atau lebih.

4) Monitor dengan resolusi minimal $1024 \times 768$.

5) Printer, Mouse dan Keyboard.

b. Printer

\subsection{Kebutuhan Software}

a. Sistem Operasi

Windows 7 SP 3 x86/x64

b. Sistem Database

MySQL Server Versi 5.5

c. Software Pendukung

MySQL ODBC Conector 3.51

Crystal Report Viewer 11

Net Framework Versi 4

\subsection{Kebutuhan Pengguna}

Adapun kebutuhan yang dibutuhkan oleh user atau pengguna yaitu pengguna harus mengetahui tentang dasar pengoperasian komputer.

\subsection{Instalasi Aplikasi}

Aplikasi sistem penggajian karyawan ini membutuhkan perangkat lunak yang telah terinstalasi, adapun tahapan-tahapan instalasi dan pengaturan (setting) sistem adalah sebagai berikut:

a. Instalasi Microsoft Visual Studio 2010.

b. Instalasi sistem operasi Windows 732 bit.

c. Instalasi aplikasi Net Framework 4.

d. Instalasi aplikasi database xampp-win32-1.8.0-VC9

e. Instalasi Mysql ODBC Connector 3.5.1

f. Instalasi Crystal Report Viewer 11

g. Instalasi sistempenggajiankaryawan (coba).

Berikut cara - cara pengaturan aplikasi :

a. Perangkat Lunak Pemograman Microsoft Visual Studio 2010

Dalam pembuatan aplikasi sistem penggajian karyawan penulis menggunakan perangkat lunak pemograman Microsoft Visual Studio 2010. Visual Studio 2010 .Net merupakan sebuah Integrated Development Environtment (IDE) atau lingkungan kerja yang digunakan untuk membangun aplikasi .Net dengan mudah. 


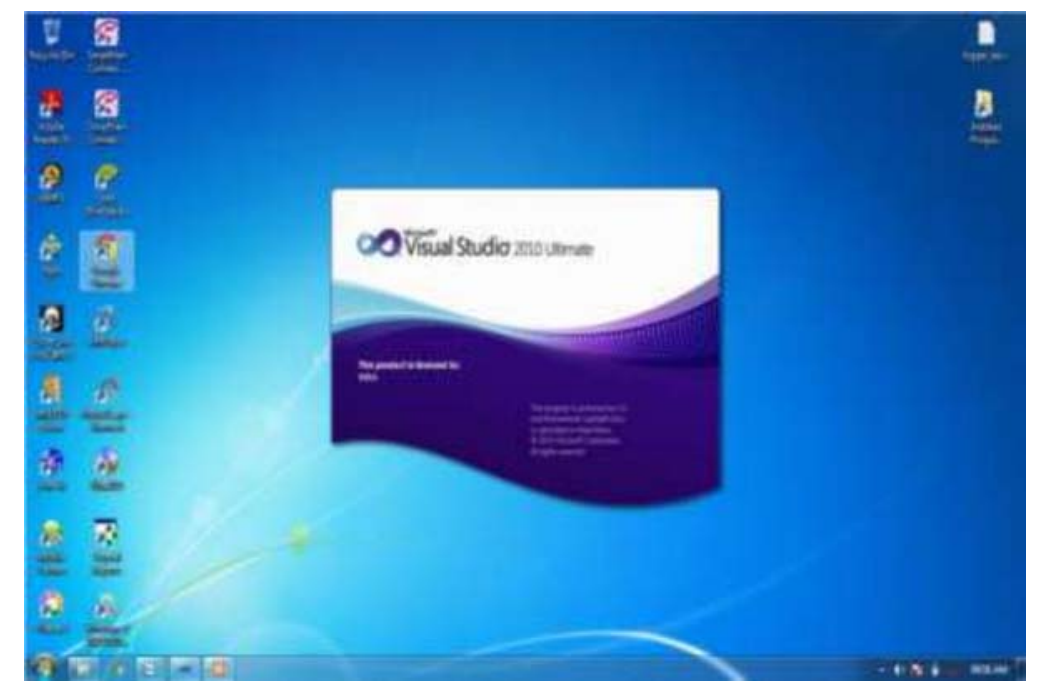

Gambar Tampilan Loading Visual Studio 2010 Ultimate

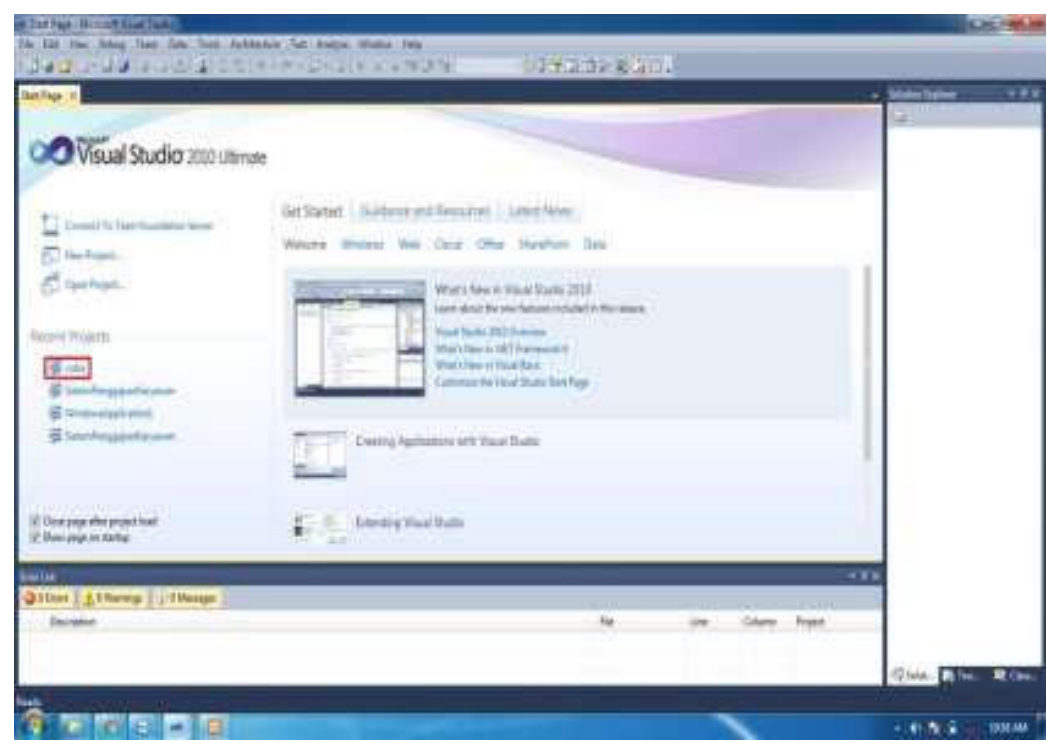

Gambar Tampilan StartUp Visual Studio 2010 


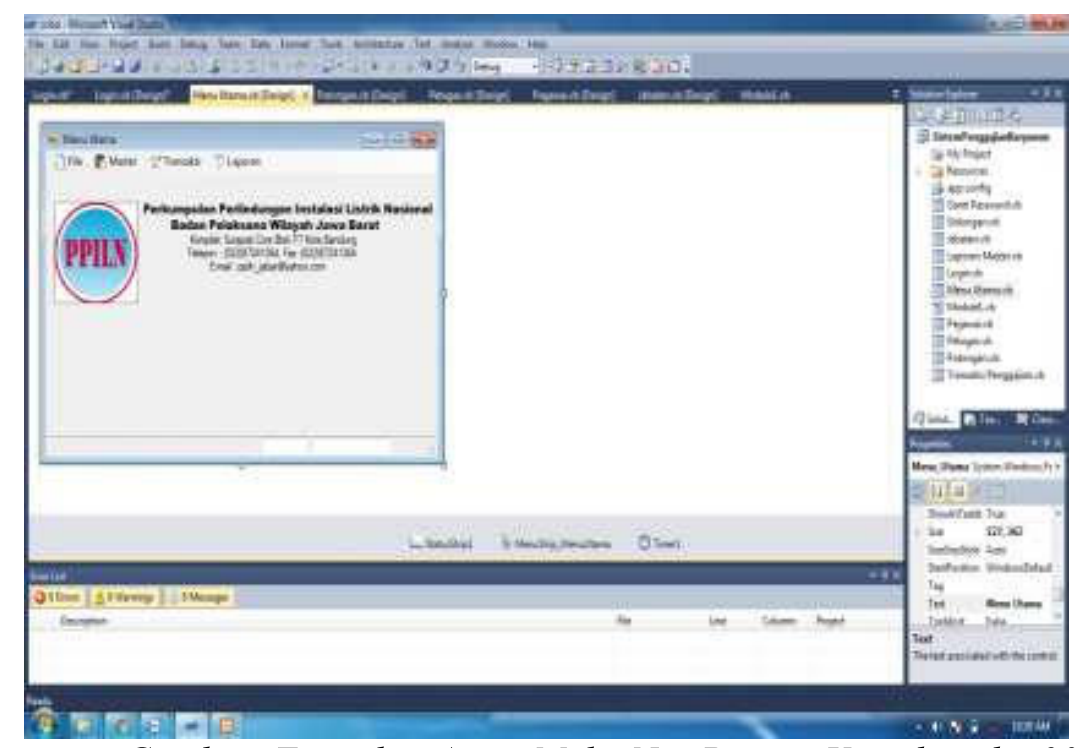

Gambar Tampilan Antar Muka NewProject Visual studio 2010

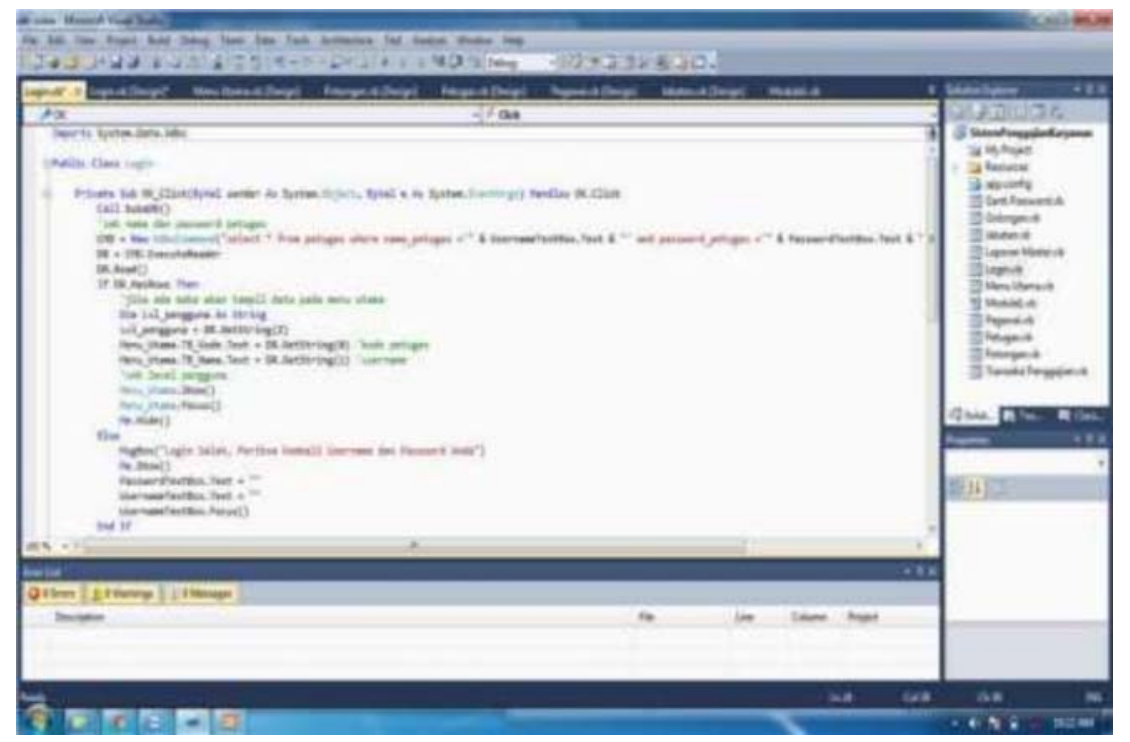

Gambar Tampilan Coding Visual Studio 2010

b. Perangkat Lunak Database Xampp

Xampp adalah perangkat lunak bebas, yang mendukung banyak sistem operasi, merupakan dari beberapa program. Fungsinya adalah sebagai server yang berdiri sendiri (localhost), yang terdiri atas program Apache HTTP Server, MySQLdatabase dan penerjemah Bahasa yang ditulis dengan bahasa pemograman PHP dan Perl. Nama XAMPP merupakan singkatan dari X (empat sistem operasi apapun), Apache, MySQL, PHP dan Perl. Program ini tersedia dalam GNU (General Public License) atau lisensi perangkat lunak bebas dan sumber terbuka, yang artinya dapat dipergunakan secara bebas oleh setiap orang dengan gratis tanpa bayar. 


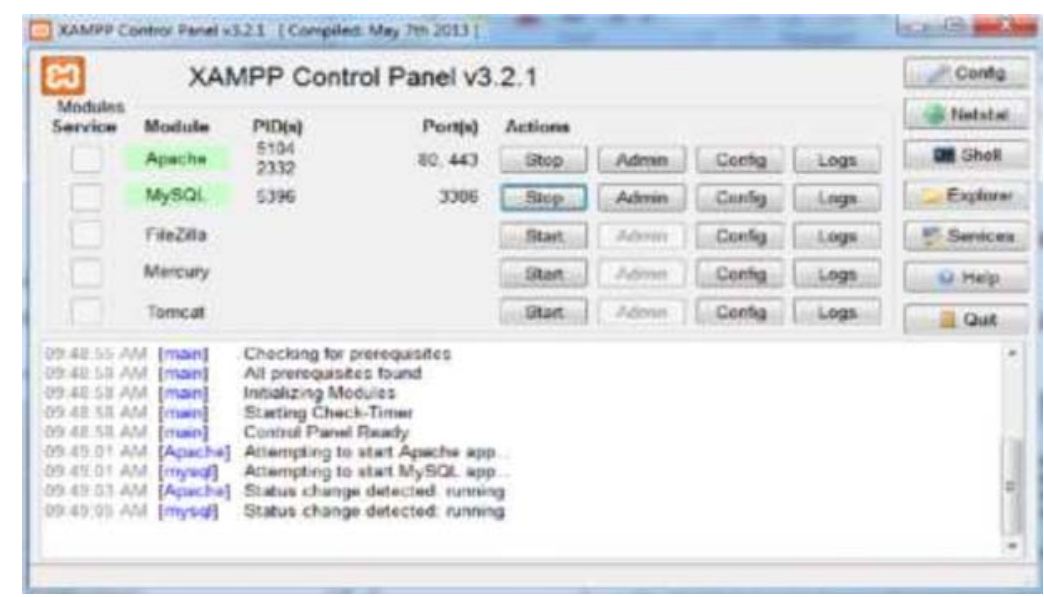

Gambar Tampilan panel control perangkat lunak xampp

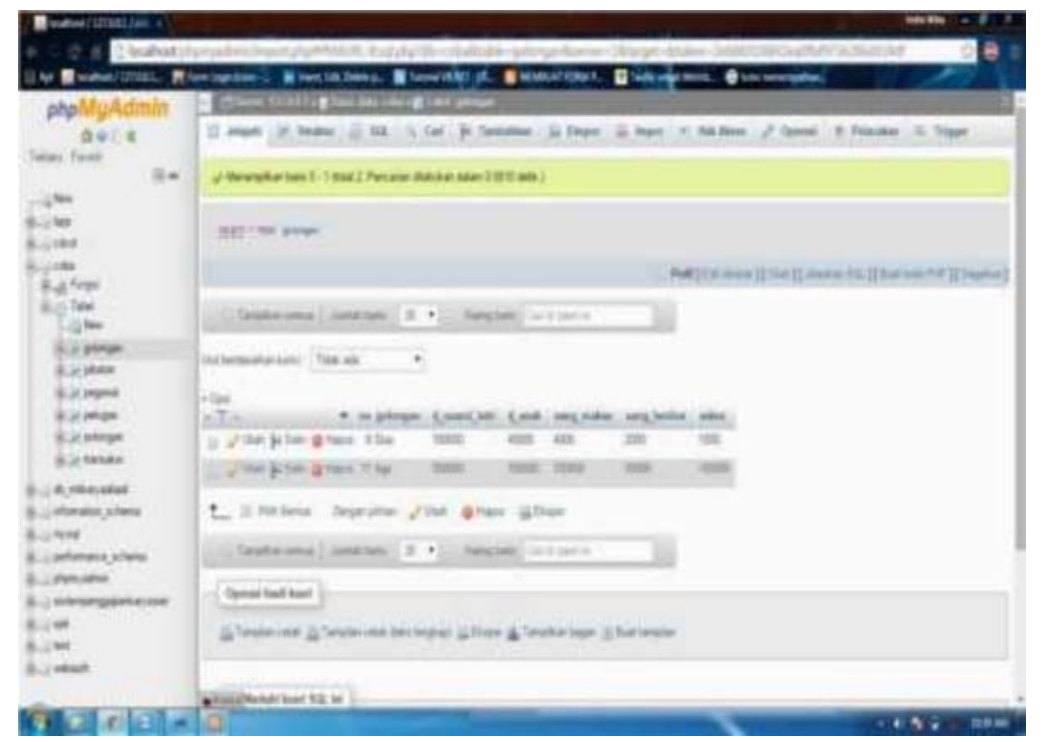

Gambar Tampilan phpMyadmin, salah satu tools dalam Xampp

c. Komponen Tambahan Mysql connector $O D B C$

Mysql connector / ODBC adalah nama untuk keluarga driver MySQL ODBC (sebelumnya disebut driver MyODBC) yang menyediakan akses ke database MySQL menggunakan standar industry Open Database Connectivity (ODBC) API. Referensi ini mencakup Connector / ODBC 5.2 yang meliputi fungsi driver Unicode dan sopir ANSI, yang sebelumnya telah dibagi antara kedua-manager berbasis antarmuka asli ke database MySQL, dengan dukungan penuh untuk fungsi MySQL, termasuk prosedur yang tersimpan, transaksi dan dengan Connector / ODBC 5.1 dan lebih tinggi, kepatuhan penuh Unicode.

1) Tekan windows $+R$ lalu isikan odbcad32 lalu enter.

2) Pilih add pada tab "user DSN" 
3) Pilih MySQL ODBC 3.51 Driver lalu klik Finish 4. Atur koneksi ODBC seperti berikut :

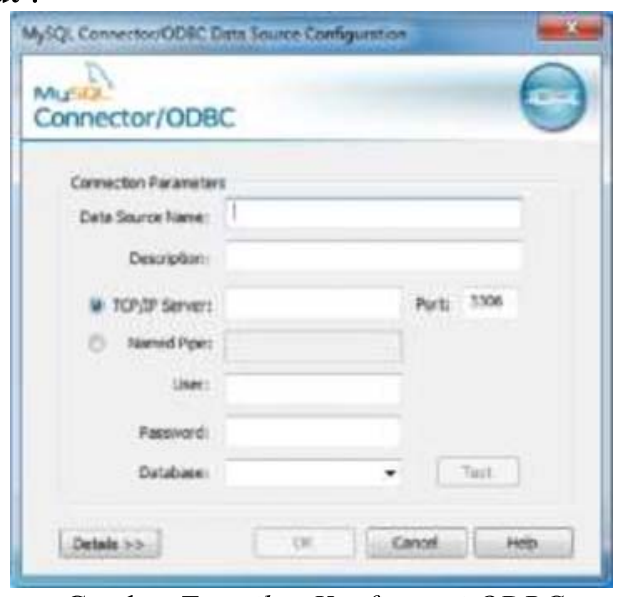

Gambar Tampilan Konfigurasi ODBC
a. Setting Data Source Name = coba
b. Description
$=$ coba
c. TCP/IP
$=$ localhost
d. Port
$=3306$
e. User dan Password
$=$ root
f. Database
$=$ coba

\section{Instalasi Aplikasi Sistem Penggajian Karyawan (coba)}

a. Copy folder Sistem Penggajian Karyawan (coba) ke C: Program Files

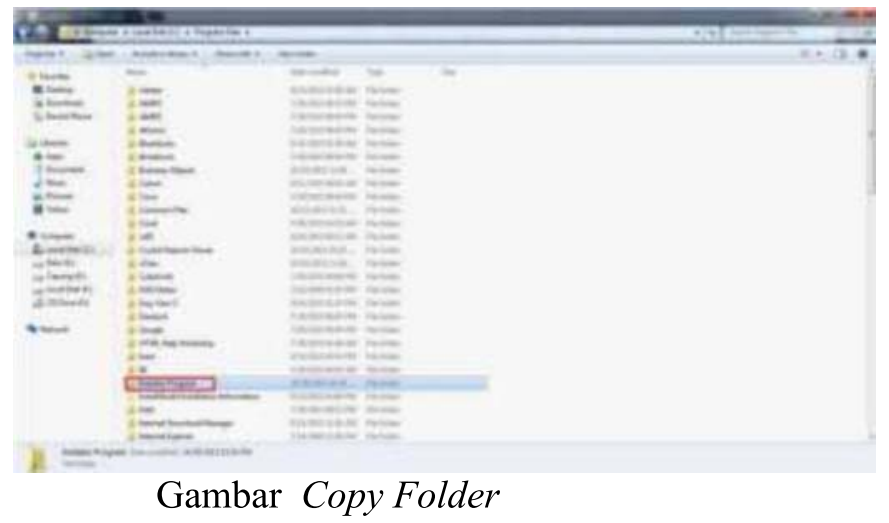

b. Buka folder Instalasi Program yang sudah di copy ke C: Program Files dan buat Shortcut coba.exe ke desktop. 


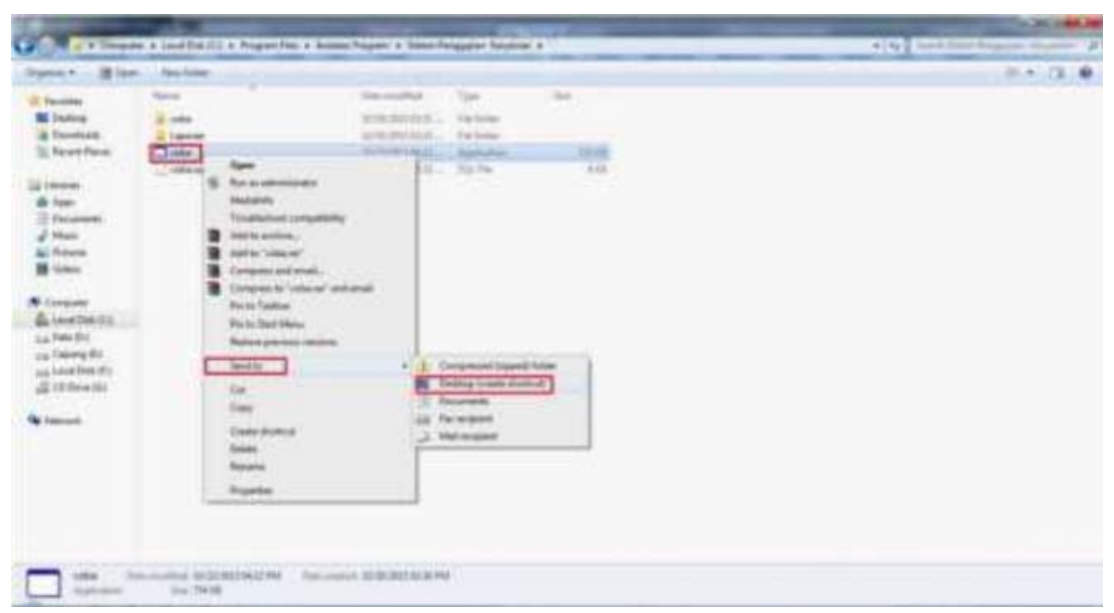

Gambar shortcut coba.exe ke desktop

c. Tekan windows + R lalu ketik "odbcad32" tanpa tanda kutip lalu enter

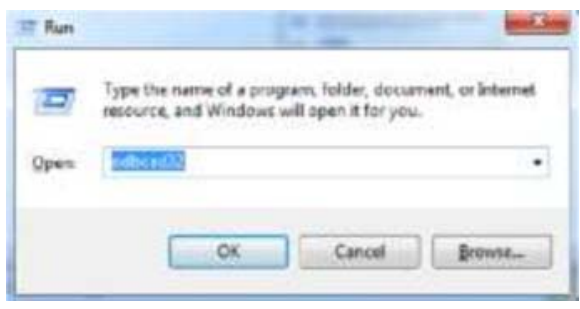

Gambar Run odbcad32

d. Konfigurasi odbc

1) Data source name = coba

2) Description = coba

3) $\mathrm{TCP} / \mathrm{IP} \quad=$ localhost

4) Port $=3306$

5) User = root

6) Password = kosongkan

7) Database $=$ coba 


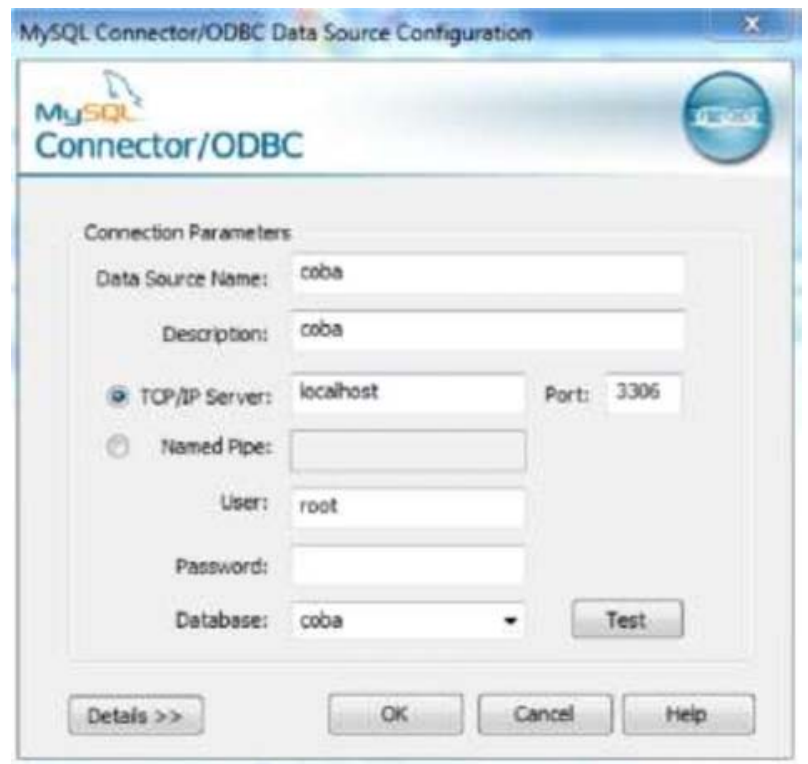

Gambar konfigurasi odbc

5. Import database coba.sql di dalam folder instalasi program ke mysql

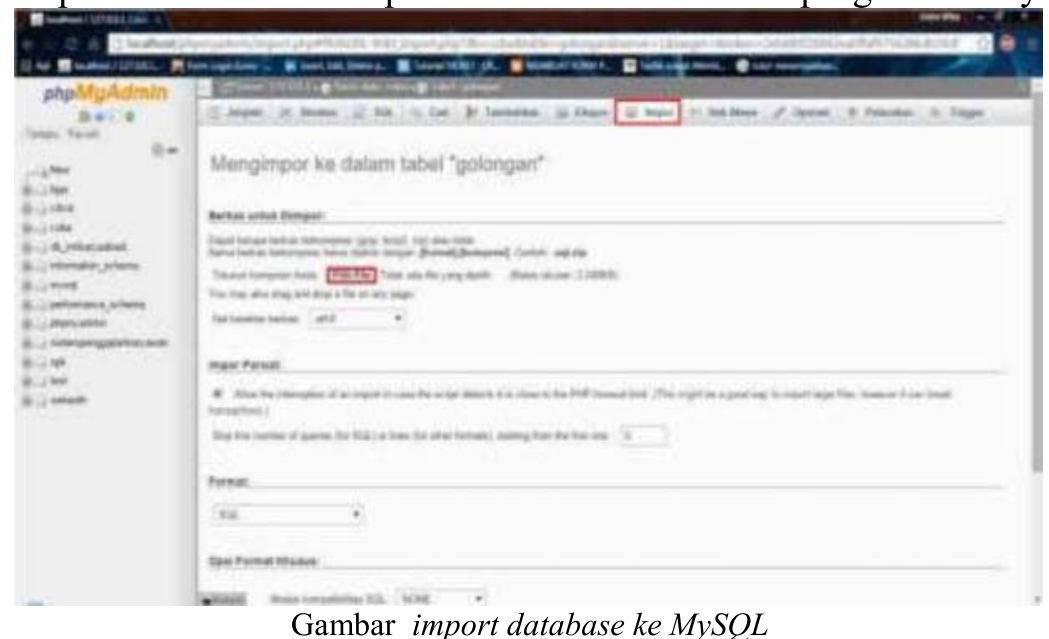

Gambar import database ke MySQL

\section{Kesimpulan}

1. Sistem Informasi Penggajian Pegawai dapat membantu dalam pengelolaan penggajian pegawai sehingga menghasilkan informasi yang valid.

2. Dengan diterapkannya sistem ini diharapkan segala kendala tentang keterlambatan dan ketidak-akuratan laporan-laporan yang berhubungan dengan masalah penggajian pegawai dapat diatasi.

3. Membantu dalam memudahkan pencarian informasi penggajian pegawai dengan pencarian informasi yang lebih cepat.

4. Dari proses perancangan ini, dapat diketahui bahwa untuk menyusun suatu sisteminformasi yang baik, tahap-tahap yang perlu dilakukan adalah dengan mempelajari sistemyang ada atau yang berlaku saat ini, erumuskan 
permasalahan yang ada, mencarialternatif penyelesaian untuk masalah yang ada, kemudian merancang suatu sistem yangdapat mengatasi masalah.

5. Sistem Informasi Penggajian Pegawai dinilai dapat dengan mudah ipelajari, mudah digunakan, dengan tampilan yang cukup menarik, menyenangkann user dan menghasilkan informasi yang valid.

\section{Daftar Pustaka}

[1] Hartono ,Yogianto.Analisa dan Desain Sistem Informasi.Yogyakarta:andi offset1995.

[2] Hartono ,Yogiantopengenalan komputer dan pemograman.Yogyakarta:andi Offset,1999.

[3] Jogiyanto,HM.Analisis \& Desain Sistem Informasi, Yogyakarta : Andi Offset. 1989

[4] Kadir, Abdul, Pengenalan Sistem Informasi. Yogyakarta : Andi. 2003

[5] Nugroho,Adi, Analisis dan Perancangan Sistem Informasi Dengan Metodologi Berbasis Objek, Bandung: Informasika Bandung, 2005

[6] Purwanto ,Edi.Teknologi Informasi Dan Komunikasi. Surakarta: Yudistira, 2004

[7] Razaq, A.R,Trik Cepat Belajar Sendiri Microsoft Access, Bandung:Yrama Widya, 2008

[8] Simartama, Janner, Payudi,Iman, Basis Data,Yogyakarta: Penerbit Andi, 2006

[9] Bab 1 Ketentuan Umum Pasal 1, Undang-Undang Kepegawaian. Pustaka Yudistira. 2006 